\title{
De krydspressede elitepiger \\ - et diskursteoretisk perspektiv på køn og eliteidræt
}

\section{Af Maja Plum, Rasmus K. Storm og Stinne Lyager Bech}

Resumé: Piger, der dyrker eliteidræt, står i en ejendommelig og paradoksal situation de er anderledes i dobbelt forstand. Anderledes $\mathrm{i}$ forhold til de mandlige standarder $\mathrm{i}$ eliteidrætsverdenen, og anderledes i forhold til de kvindelige markører i det omgivende samfund. Dette skaber et svært håndterligt krydspres. I artiklen udfoldes et diskursteoretisk perspektiv på denne dobbelte anderledeshed, og konsekvenserne for pigernes til- og fravalg af elitekarrieren analyseres.

\section{Indledning}

Flere danske idrætsgrene står med et problem. Efter trænernes og klubbernes egen vurdering findes der en række piger i alderen 15-18 år med masser af talent, som ikke - i samme omfang som drengene - vælger at satse på deres idræt. I stedet vælger de idrætten helt fra eller stopper med at dyrke den på eliteniveau. Med repræsentanter for idrætsgrenene badminton, tennis, bordtennis og håndbold har Team Danmark derfor taget initiativ til en undersøgelse af, hvorfor pigerne ikke vælger at satse på deres idræt. I undersøgelsen »Elitekarriere på spil«, hvis resultater denne artikel bygger på1, søger vi at kaste lys over dette oplevede problem ved at fokusere på to primære kontekster, som vi mener pigernes liv udspiller sig indenfor: På den ene side en idrætslig kontekst, hvor den daglige træning, konkurrencerne, klubben, kollegaer, venner og trænere er omdrejningspunktet, og på anden side, det man kan kalde en »civil« kontekst, hvor familie, uddannelse og venner er i fokus. Disse to kontekster skal ikke forstås som gensidigt ekskluderende kategorier, men er i praksis overlappende. Pointen er, at vi i vores tilgang til problemstillingen udpeger to analytiske kontekster, hvori vi mener, at forskellige normer, værdier og forståelsesrammer - eller diskurser - dominerer. ${ }^{2}$ I undersøgelsen søger vi at indfange, hvordan disse diskurser former sig, og hvorledes pigerne forvalter deres egen rolle $\mathrm{i}$ forholdet mellem disse. $^{3}$ Med udgangspunkt i resultaterne fra undersøgelsen vil vi i nærværende artikel udfolde et teoretisk perspektiv på det identifikatoriske krydspres, pigerne giver udtryk for at stå i, mellem den idrætslige og civile kontekst. Dette gøres med henblik på at forstå, hvad der er på spil, når elitepiger falder fra.

\section{Om undersøgelsen}

Undersøgelsen fandt sted inden for de fire ovenfor ncevnte sportsgrene, og omhandlede kvindelige udøvere $i$ alderen 15-18 år, der af trcenere og sportschefer fra deres respektive forbund blev vurde- 
ret til at have potentiale til at nå den $a b-$ solutte elite. For badmintons vedkommende var dette U17 og U19 elitespillere, for håndbold var det bruttotrupperne til dameungdoms- og ynglingelandsholdene, mens der for tennis- og bordtennisspillernes vedkommende var tale om deltagerne $i$ de respektive nationale talentprogrammer. De $i$ alt 125 udøvere udgjorde undersøgelsespopulationen. Arsagen til, at netop badminton, bordtennis, håndbold og tennis blev udvalgt til undersøgelsen, var, at trcenerne her oplevede frafalds-og motivationsproblemer.

I den empiriske undersøgelse indgik både kvalitative og kvantitative elementer - henholdsvis fokusgruppeinterview med udøvere, trænere og frafaldne udøvere samt uddybende individuelle kvalitative interview med udøvere og tidligere udøvere samt en kvantitativ spørgeskemaundersøgelse blandt samtlige i undersøgelsespopulationen. For en nærmere gennemgang af selve den empiriske undersøgelse og dens metode henvises til Beck et al. 2004.

\section{Et anderledes liv og køn: eksisterende forskning}

En række empiriske undersøgelser om eliteidræt har i de senere år givet indsigt i, hvordan eliteidrætsudøveres liv former sig. ${ }^{4}$ Fælles for disse undersøgelser er, at de peger på eliteidrætsudøveres liv som en tilværelse, der på mange måder er forskellig fra andre menneskers. Fokus på sporten både tidsmæssigt og socialt har stor betydning. Således indebærer et idrætsliv ofte midlertidigt eller permanent fravalg inden for den civile kontekst af uddannelse, civil karriere og sociale aktiviteter med familie og venner uden for sporten.

Undersøgelser, der retter sig mod at forstå kønnets betydning i relation til den sportslige arena, fik for alvor sit gennembrud i løbet af 80'erne. ${ }^{5}$ Disse undersøgelser viser gennemgående, at den idrætslige verden er mandsdomineret. ${ }^{6}$ Selv om der i dag er langt flere sportsgrene, der har åbnet for kvindelig deltagelse, har sport fortsat et institutionelt og kulturelt center, der strukturerer opfattelsen af kønnet i sport - det er konstrueret af og for mænd. ${ }^{7}$ Messner og Sabo beskriver således, hvordan sporten har spillet en central betydning for skabelse af hegemonisk maskulinitet. ${ }^{8}$ I relation til vores undersøgelse kan man i den forbindelse sige, at den anderledeshed, der ligger i tilvalget af elitekarrieren og fravalget af aktiviteter inden for den civile kontekst, således er med til at understøtte de mandlige udøveres maskulinitet og forstærke deres samfundsmæssige køn. Messner og Sabo kaster samtidig et blik på, hvordan relationer mellem køn fungerer i idræt, men også på hvordan dette afspejler og afspejles i relationerne mellem køn i andre sammenhænge.

Et sådant blik er styrket $i$ takt med fremkomsten af postmodernistiske strømninger inden for feministisk teori, hvor studier af relationen mellem sport og køn, der opfatter kønnet som noget, der konstrueres i sociale processer ${ }^{9}$, har vundet indpas. ${ }^{10}$ Med dette perspektiv rettes der fokus mod sporten som en arena for skabelse, forhandling og grænsesætning af kønnet. Magt bliver i et sådant perspektiv ikke opfattet som noget, mænd besidder og udøver over kvinder, men som enhver handling, der påvirker andre handlinger ved at forme de handlende aktørers identitet, kapacitet og meningshorisont. ${ }^{11}$ Dermed udvides forskningsfeltet til 
at omhandle historisk specifikke sociale konstruktioner af køn i idræt samt de forskellige hverdagslige forhandlinger og reproduktioner af disse, blandt andet $\mathrm{i}$ idrætsudøvernes egne hverdagspraksisser og identifikationsprocesser. Det følger ligeledes af den socialkonstruktivistiske strømning, at (køns)identitet ikke opfattes som en indre personlighedskerne, men netop som noget, der konstrueres i sociale relationer, eksempelvis i den idrætslige kontekst. Det er denne tradition, som nærværende artikel søger at skrive sig ind $i$.

I den forbindelse bliver kvindens positionering som »det andet køn« i relation til mænd centralt. Det anderledes liv, der følger med eliteidrætskarrieren, kan være med til at definere mandlige udøverne som $»$ mere mænd «, men for kvindelige udøvere er situationen ikke helt den samme. Chapman ${ }^{12}$ har med sit Foucault-inspirerede studie af kvindelige roere vist, at den daglige programmering af træning og fødeindtagelse for at komme ned i vægt ikke alene er noget, de kvindelige atleter forbinder med at blive en god sportsudøver, men også med det at være en attraktiv kvinde. Her indebærer eliteidrætten ligeledes praktikker, som delvist underbygger det samfundsmæssige køn. Men samtidig giver de kvindelige roere udtryk for, at de gennem sporten opbygger en muskuløs krop, der er anderledes end idealet for den kvindelige krop. Dette udfoldes også af Larsson ${ }^{13}$, der primært inspireret af Judith Butler beskriver, hvordan elitepigerne oplever en splittelse mellem idealet om deres muskuløse »præstationskrop« og idealet om »den smukke krop«, hvor muskler ikke indgår i det kvindelige ideal. Anderledeshed i forhold til en traditionel forståelse af femininitet er særdeles markant i Fasting, Pfister og Scratons studie af kvindelige fodboldspillere $\mathrm{i}$ fire forskellige lande. ${ }^{14} \mathrm{Her}$ sættes fokus på, hvorledes de kvindelige udøvere udfordrer og forhandler de traditionelle kvindestereotyper, i og med at de gennem deres idræt optræder på måder, der traditionelt forstås som ufeminint. Man kan tale om en identifikatorisk anderledeshed, der handler om, at de kvindelige idrætsudøvere gennem deres tilegnelse af idrættens maskuline markører adskiller sig fra de elementer, der i vores vestlige samfund for nærværende forbindes med det at være kvinde. $^{15}$

Tilegnelse af maskuline markører betyder imidlertid ikke, at de kvindelige udøvere uproblematisk bliver de samme som - eller opnår samme status som - de mandlige idrætsudøvere. En række undersøgelser peger på, at såvel kvindesport, som de piger og kvinder, der dyrker den, qua deres køn indtager rollen som outsidere eller må overvinde en række barrierer for at blive betragtet på lige fod med drengene. ${ }^{16}$ Larsson $^{17}$ giver et billede af såvel trænere som udøveres konstruktioner af køn i idræt. Han konkluderer, at de værdier, der sættes centralt inden for idræt, overvejende er maskuline, såsom aktivitet, disciplin, vilje, målrettethed etc. Det billede som idrættens piger, drenge og trænere giver af drenge inden for idræt, svarer meget overens med sådanne sportslige eller maskuline værdier. Firkantet stillet op fremstår drengene som de uproblematiske i forhold til idrætten: De er aktive, handlende, fornuftige, enkle at have med at gøre og konkurrencemindede. Pigerne fremstår derimod - ligeledes firkantet stillet op - som problematiske: De er passive, svære at kommunikere med for trænere, og de kan ikke konkurrere, uden at det udvikler sig til negative personlige opgør. Der er tale om en identifikatorisk anderledeshed, hvor pigerne identificeres qua deres køn som anderledes $\mathrm{i}$ forhold til billedet af 
den »gode« eliteidrætsudøver, endsige den mandlige.

De beskrevne undersøgelser peger på, at idrætsudøvere generelt lever en tilværelse, der på flere områder adskiller sig fra de, der ikke dyrker eliteidræt. Dels er der tale om en konkret anderledeshed i måden at bruge sin tid og energi på. Dels peger de mere kønsfokuserede undersøgelser på en identifikatorisk anderledeshed, hvor kvindelige idrætsudøvere identificeres og identificerer sig som anderledes både i den idrætslige og den civile kontekst. Det er disse konkrete såvel som identifikatoriske former for anderledeshed, der er omdrejningspunktet for vores undersøgelse. Vi læner os op ad et socialkonstruktivistisk udgangspunkt og ser - som for eksempel Larsson ${ }^{18}$ og Chapman $^{19}$ - på de måder, hvorved pigerne støder ind i, slås med, udfordrer, men også underbygger en hel række af traditionelle opfattelser og værdihierarkier bygget op omkring forskelssætningen mellem det maskuline og det feminine. Ligesom Larsson ${ }^{20}$ sætter vi således fokus på, hvordan pigerne håndterer deres møde med den maskulint definerede eliteidræt, men vi sætter også fokus på pigernes identifikationer i denne proces. I behandlingen af datamaterialet synes forholdet mellem de to dominerende kontekster det, vi her kalder »den civile« og den idrætslige - nemlig at fylde meget som et altid nærværende konfliktfyldt forhold på det identifikatoriske plan, idet pigerne giver udtryk for en konstant nærværende splittelse mellem de to kontekster. På den baggrund inddrager vi i denne artikel et diskursteoretisk perspektiv, som ligeledes læner sig op ad et poststrukturalistisk udgangspunkt, og hvor fokuset er på at forstå, hvorledes pigerne søger at håndtere den grundlæggende splittelse, står centralt. Det er vores opfattelse, at diskursteorien åbner en analytisk- teoretisk mulighed for at forstå, hvorledes den identifikatoriske anderledeshed får betydning for fravalg af elitekarrieren og dermed ophøret af den konkrete anderledeshed.

\section{At voere anderledes end almindelige piger}

Pigerne i undersøgelsen oplever fra en tidlig alder, at deres liv former sig anderledes end piger uden for idrætsverdenen. De kredser om en følelse af at skille sig ud og have andre interesser, ligesom flere oplever sig som »klassens turist « i skolen. Pigerne giver udtryk for, at de bliver opfattet som anderledes i forhold til andre piger og føler, at de forventninger, som de mødes med fra deres venner uden for sporten, er uforenelige med deres egne prioriteringer:

»Man har svært ved at skuffe veninderne, hvor hvis det var en dreng, han sagde, at han skulle ud og spille fodbold på landsholdet, så synes vennerne, at han var sej, hvor at pigerne hellere vil være sammen og gå ud at shoppe sammen og sidde og hygge sig. De synes jo, at det er lidt mærkeligt, at man gider dyrke så meget sport«. ${ }^{21}$

Dette er en kilde til frustration, og mange af pigerne udtrykker et savn efter »bare at være en almindelig pige«. Samtidig identificerer pigerne sig imidlertid også aktivt i modsætning til »de almindelige piger «. De italesætter dem som nogen, der shopper, drikker te og går op i deres udseende, mens de selv som elitepiger lever et aktivt liv og har et afslappet forhold til deres udseende. At være elitepige åbner således en række muligheder for pigerne, og flere fortæller, hvordan det blandt andet er muligheden for at agere ufeminint, som de værdsætter ved at dyrke sport: 
»Piger, der spiller sport, $i$ hvert fald på det hold, hvor jeg har spillet, er meget drenge. Altså fjoller rundt og er lidt ulcekre engang imellem, hvis du forstår, hvad jeg mener (latter). Altså, man er ligeglad, man bøvser, og man prutter, og man laver alt muligt, altså på sådan nogen ture, man bliver virkelig sådan ikkefeminin (...). Også når man snakker med fyre om sportspiger, så siger de: De er bare så ulcekre, de er ikke feminine, de er bare ligesom fyre selv, ik'. Fordi man ér bare, altså afslappet, ikke!? "22

At være ufeminin forbindes således med at være afslappet, ligesom der blandt elitepigerne eksisterer en fælles fortælling om de almindelige pigers lidt overdrevne fokus på eget udseende som noget negativt.

\section{At vare anderledes $i$ idrcetsverdenen}

Undersøgelsen af elitepigerne understøtter mange andre undersøgelsers konklusioner - herunder de ovenfor gennemgåede - om, at idrætsverdenen er mandsdomineret. Helt konkret er de fleste af de sportsgrene omfattet af undersøgelsen, domineret af mandlige idrætsudøvere og trænere på topplan. For eksempel er kun $14 \%$ af pigernes trænere kvinder. Pigerne har en oplevelse af, at trænerne opfatter dem som vanskeligere end drengene, og måler dem negativt $\mathrm{i}$ forhold til drengenes præstationer. Trænerne menes også at have sværere ved at kommunikere med pigerne, fordi »Trcenerne som regel er moend, og der er stor forskel på moend og kvinder. Så de ved ikke rigtig, hvad det er, piger går igennem «. ${ }^{23}$ Pigerne fremhæver alle forståelse som det helt afgørende forhold i relationen til træneren, og manglende forståelse og dårlig kommunikation er lig en dårlig træneroplevelse. En pige beskriver eksempelvis en konflikt med en træner, hvor hun oplevede, at han satte den samme standard for, hvordan hun selv og en dreng, der var på samme niveau, skulle træne. Men: »En dreng og en pige synes jeg ikke skal trane på samme måde, fordi en dreng synes jeg er bygget fysisk stcerkere end en pige er, og en pige skal måske trcene på en lidt anderledes måde« ${ }^{24}$ Respondenten fortæller videre, at hun ikke kunne holde til træningen og fik skader. Derfor gjorde hun opmærksom på, at hvis hun skulle kunne holde til at spille på langt sigt, måtte hun træne på en anden måde end drengen. Herefter oplevede respondenten, at »jeg ligesom $r ø g u d$ «, og at træneren koncentrerede sig om drengens træning. Pigens oplevelse af sig selv og trænerens oplevelse af hende stemte ikke overens. Hvad han ifølge pigen opfattede som manglende målrettethed og motivation, oplevede hun som at blive målt efter forkerte standarder, hvor drengen blev fællesnævneren, og der ikke blev taget hensyn til hende som person (og pige). Pigerne oplever altså at støde ind i nogle implicitte billeder af, hvordan »rigtig « træning ser ud, og hvorledes »rigtige« eliteudøvere bør opføre sig. Samtidig italesætter pigerne selv drengene som bedre idrætsudøvere end piger. Værdier som selvsikkerhed, konkurrenceånd og målrettethed, der står centralt $\mathrm{i}$ sportens verden, defineres af de fleste piger, som noget drenge i højere grad end piger besidder. De positive sider, som pigerne fremhæver hos deres eget køn, er omsorg for hinanden og mindre aggressivitet. Begge dele kan og bliver opfattet som en hindring for gode sportsresultater. Pigerne reformulerer samtidig disse karakteristika som noget, der danner grobund for et godt socialt miljø, og at de i modsætning til dren- 
gene ikke er unødigt aggressive eller vinderfikserede. Pigerne er altså ikke som de andre drenge $\mathrm{i}$ idrætten. Trods deres forskellighed fra »almindelige piger« bliver de ikke automatisk lig med de maskuline idealer, som de forbinder med og oplever at blive mødt med i idrætslige sammenhænge.

\section{Et diskursteoretisk blik på pigernes situation}

Ovenstående viser, hvordan pigerne både i den idrætslige og den civile kontekst oplever at blive ekskluderet fra det almindelige og også aktivt definerer sig selv som anderledes i begge sammenhænge. Der er tale om en oplevet anderledeshed, der i forhold til et diskursteoretisk perspektiv kan forstås som en konkret anderledeshed i måden at indrette sit liv, der igen giver sig udslag $i$ en identifikatorisk anderledeshed, nemlig ikke til fulde at kunne identificere sig med og ikke blive identificeret med henholdsvis billedet af en almindelig pige og en god eliteidrætsudøver. Det interessante er, at pigerne forvalter denne paradoksale og samtidige mulighed og umulighed for identifikation som en form for dobbelt anderledeshed. Generelt omtaler pigerne sig selv som »drenge-piger«, og de skaber på denne måde en paradoksal og umiddelbar ejendommelig identifikationsmulighed som dobbelt anderledes. Det vil sige som nogen, der - i kraft af, at de er piger - på én gang ikke lever til fulde op til de maskuline karakteristika, der præger idrætskonteksten, og samtidig - som eliteidrætsudøvere - ikke til fulde bærer de feminine karakteristika som forbindes med at være »almindelig pige« $\mathrm{i}$ den civile kontekst.

Begrebet, »dobbelt anderledes «, konstruerer vi således i relation til de oplevelser, pigerne har af deres egen situation. Analytisk forbinder vi dette med, hvad vi har beskrevet som såvel en konkret som en identifikatorisk anderledeshed. Det dominerende i pigernes oplevelser er imidlertid ikke alene et spørgsmål om, at de strukturerer deres liv anderledes end normen eller om en identifikatorisk anderledeshed i henholdsvis den ene eller anden kontekst. Snarere vil vi sige, at der er tale om et konstant nærvær af at være anderledes i begge kontekster. Pigernes forvaltning af egen rolle kan i høj grad forstås som en måde at støde ind i og udfordre gældende kønskonventioner, men for at forstå fravalget af eliteidrætten - og dermed tilvalget af et civilt liv indrettet efter normen og en identifikation med et mere traditionel kvindebillede - mener vi, at der er behov for at fokusere på den splittelse, pigerne giver udtryk for i det kontante nærvær af at være anderledes både i den ene og den anden kontekst. Det er netop denne splittelse som en konstant mulighed og umulighed for identifikation, som vi mener, diskursteorien ${ }^{25}$ kan hjælpe med at begrebsliggøre. Begrebet »overdetermination « bliver i denne forbindelse centralt, idet begrebet definerer en situation, hvor subjektet er splittet mellem flere og ofte modstridende identiteter samtidigt. ${ }^{26}$ Begrebet fanger det negative ontologiske perspektiv, diskursteorien opererer med: Det sociale kan ikke forklares eller afgøres i forhold til en sidste determinerende instans, $f x$ den økonomiske basis. I stedet må identifikation og mening ses som noget, der er kontingent og anti-essentialistisk. Noget, der ikke er givet i sig selv. Derimod er mening et »resultat« af de kampe, der hele tiden foregår om at betydningstillægge social interaktion. Det er denne midlertidige fiksering af mening i en form af et struktureret mønster, en menings- og identifikationshorisont, der kaldes 
en »diskurs « ${ }^{27}$ Væsentligt i denne sammenhæng er, at en diskurs opsætter foreløbige grænser og muligheder og aldrig kan lukke sig om sig selv, fordi den ikke kan fastgøres positivt; men fikseres gennem negationen til det, den ikke er. Det, der stilles uden for diskursen, virker således på én gang konstituerende, men også truende for diskursens identitet. ${ }^{28}$ Eliteidræt (eksklusivt) får eksempelvis sin betydning gennem modsætningen til breddeidræt (inklusivt) eller helt andre sociale institutioner, som familien, skolen etc. Der er med andre ord ikke tale om en korrespondance mellem et bestemt fænomen og den »sande« forståelse heraf, men om modsatrettede konkurrerende forståelsesrammer, der på én gang konstituerer og truer diskursens endelige fiksering. ${ }^{29}$

Set i forhold til identifikationsmuligheder for elitepigerne betyder det, at der altid vil være flere diskurser, der stiller forskellige og måske endda modsatrettede subjektpositioner til rådighed for identifikation. Den herskende diskurs inden for den civile kontekst stiller således en subjektposition til rådighed, mens der i idrætskonteksten stilles en anden til rådighed. Overskuddet af identifikationsmuligheder behøver imidlertid ikke at blive oplevet problematisk. De fleste af os indtager hver dag en række subjektpositioner som henholdsvis lønarbejder, bestyrelsesmedlem, mand etc., uden at vi oplever dette som konfliktfyldt. Men set diskursteoretisk indgår enhver af disse subjektpositioner imidlertid i en række modsætningsrelationer til andre tilgængelige diskurser/subjektpositioner. Det er her, den gensidige mulighed og umulighed kommer på banen, idet de alternative subjektpositioner på en gang udgør de poler, som en identifikation kan foregå i forhold til, men samtidig umuliggør en fuldstændig identifikation. ${ }^{30}$ Principielt set er enhver situation så- ledes overdetermineret; men det er samtidigt en gennemgående pointe hos Laclau og Mouffe, at overdetermination i praksis kun forekommer sjældent. Nok er identifikation $\mathrm{i}$ teorien fuldstændig åben, men da kun Vor Herre - populært sagt - kan holde de fuldstændigt ufikserede situationer ud, dulmes det flertydige kaos, som det essentielle fravær af en absolut identifikationsmulighed efterlader, altid af den sociale fiksering. ${ }^{31}$ Den sociale situation er med andre ord som hovedregel stabil, og de subjektpositioner, vi løbende indtager, er typisk konstitueret gennem negationer, der ikke virker som en konstant og nærværende trussel.

Ser vi imidlertid nærmere på elitepigerne, er det interessante, at deres situation aldrig er stabil. De subjektpositioner, der tilbydes $\mathrm{i}$ henholdsvis den civile og den idrætslige kontekst, er i høj grad konstitueret gennem negationen til hinanden. Pigerne lever således i en radikal - eller hele tiden tilstedeværende - overdetermineret situation. I henholdsvis den idrætslige og civile kontekst står de bogstaveligt talt splittet. Qua deres socialt konstruerede køn tilbydes de i den civile kontekst muligheden for subjektpositionen »pige« samtidig med, at de pådrages - qua deres tilknytning til eliteidrætten - markører, der tilbyder dem subjektpositionen »dreng «. Elitepigerne synes således at være fanget $\mathrm{i}$ en faktisk levet paradoksal og samtidig mulighed og umulighed for identifikation.

\section{»Drenge-piger« - investering $i$ en dobbelt negation}

Med diskursteoretiske termer står elitepigerne dermed imellem to dominerende dis$\operatorname{kurser}^{32}$, der stiller konkurrerende subjektpositioner til rådighed. På den ene side en 
diskurs, der hersker i den civile kontekst, der konstruerer piger som omsorgsfulde, passive piger, der interesserer sig for deres udseende, shopper osv. og dermed stiller en identifikation eller subjektposition som »pige-pige« til rådighed. I kraft af pigernes tilvalg af sporten er denne identifikation imidlertid ikke en reel mulighed for dem, eller som en af pigerne udtrykker det: »man kan aldrig vare en pige-pige« og samtidig udøve sin sport på højt niveau..$^{33}$ Det er således vanskeligt at være idrætspige samtidig med at være almindelig pige, idet kravene, de to identifikationsmuligheder stiller til subjektet, står i modsætning til hinanden de er i princippet gensidigt ekskluderende. På den anden side står en idrætslig diskurs, der definerer drenge som normen for god idrætslig opførsel. Pigerne oplever dermed at blive defineret som »de anderledes « $\mathrm{i}$ den idrætslige sfære og opfatter også sig selv som anderledes. De kan således ikke uproblematisk indtage subjektpositionen som eliteidrætsudøver, fordi denne bliver defineret ud fra maskuline elementer. Vi vil kalde denne identifikationsmulighed for »dreng-dreng « for at understrege, at pigerne reelt er ekskluderet fra den.

Helt centralt for forståelsen af pigernes identifikation i denne situation er Laclaus skelnen mellem de subjektpositioner eller identifikationsmuligheder, der stilles til rådighed i en given diskurs, og den identifikation, dvs. det valg (her ikke forstået i en rationel forstand), der konstituerer subjektet ved netop at skabe en midlertidig lukning, der dulmer det flertydige kaos. Det fremhæves herved, at subjektet ikke udelukkende konstitueres som en interpellering af diskursen, men også er udtryk for en investering i subjektpositionen. ${ }^{34}$ Idet strukturen ikke kan definere sig selv fuldt ud, fordi lukning ikke er mulig, kan den heller ikke determinere subjektet endeligt. Denne mangel på fuldkommen fiksering og identifikation kræver således et forsøg på lukning gennem beslutning eller valg. Subjektet kommer så at sige til syne i sit forsøg på at dulme det grundlæggende meningskaos ved aktivt at investere sig selv $i$ en given identifikationsmulighed.

Elitepigernes identifikation som »drenge-piger « - eller som »en af drengene selv om man er en af pigerne $\ll^{35}$ som en pige udtrykker det - kan på denne baggrund forstås som en særlig konstellation, hvor der investeres i to gensidigt udelukkende identifikationsmuligheder. En investering i subjektpositionen »eliteudøver« tilbyder ikke elitepigerne en lukning, fordi den negerer de elementer, der forbindes med det at være pige i civilsfæren. Ligeledes gælder det i forhold til subjektpositionen »almindelig pige«. Manglen er med andre ord konstant nærværende i begge de dominerende identifikationsmuligheder, der tegner sig. Det interessante er, at elitepigerne håndterer denne mangel ved en investering i negationer til elementer i såvel det maskuline som det feminine. De ignorerer med andre ord fraværet af en oplagt identifikationsmulighed gennem en paradoksal identifikationshåndtering. Således har vi set, hvordan pigerne på den ene side definerer sig i modsætning til en identitet som »pige-pige « og har fremhævet muligheden for at agere ufeminint som en fordel ved sporten, mens de samtidig på den anden side definerer sig i modsætning til en »dreng-dreng-identitet«, som de forbinder med aggressivitet og vindermentalitet. Dermed gør pigerne aktivt brug af, at de er piger, når de skal finde deres rum inden for sporten samtidig med, at de indoptager mandlige elementer i deres kønskonstruktion i forhold til den sociale situation, de er sat i. Det særlige ved elitepiger- 
nes identifikation synes på denne måde at være installationen af en dobbeltnegation som et altoverskyggende centrum for deres identitet. Identiteten som »drenge-pige« skabes dermed i det dobbelte modsætningsforhold til »dreng-dreng« og »pige-pige« og elitepigerne mødes konstant med kravet om at indoptage de værdier, der knyttet til disse to positioner - de skal være konkurrencemindede OG omsorgsfulde, aktive OG passive, de skal være både-og og hverken-eller.

\section{Fravalg af eliteidrcetten som udtryk for en (midlertidig) lukning}

Identifikationen som »drenge-piger« kan herved forstås som en evig balancegang mellem de to positioner - en balance på en knivsæg, hvor selv den midlertidige lukning synes svær at fastholde, og hvor det flertydige kaos dulmes gennem en konstant jonglering mellem opretholdelse og ophævelse af modsætninger.

At investere sig selv identifikatorisk som »drenge-pige« er dermed heller ikke uproblematisk, og det stiller løbende spørgsmålstegn ved identitetshåndteringen. I undersøgelsen giver pigerne udtryk for, at de med jævne mellemrum overvejer at stoppe med eliteidrætten. ${ }^{36}$ Tvivlen dukker typisk op i forbindelse med skader, skift (fra en klub til en anden eller en række til en anden), manglende sportslige resultater eller en oplevelse af ikke at blive bakket op af træneren. Derimod synes venner og families opbakning eller mangel herpå ikke at udløse tvivl. Det er således typisk, at pigernes overvejelser om at stoppe elitekarrieren opstår i forbindelse med, at det bliver muligt at stille spørgsmålstegn ved deres vindermen- talitet, deres målrettethed, styrke eller konkurrenceevne. Flere af elitepigerne fremhæver på den baggrund, at de som piger er langt dårligere til at tackle modstand end drengene, der ofte fortsætter ufortrødent trods modgang. Set i et diskursteoretisk perspektiv er det interessante i elitepigernes tvivlssituationer, at de konsekvent opstår, idet fastholdelsen af typiske maskuline karakteristika begynder at skride. Det er her, det bliver svært ikke alene at være i den idrætslige kontekst; men også at være i den civile kontekst. Som elitepigerne påpeger, er der i sådanne situationer ikke noget, der retfærdiggør deres mangel på deltagelse i fester, familiesammenkomster eller andre af det »almindelige pigelivs« aktiviteter. De kan ikke opretholde at være de anderledes sportspiger, der dukker op til fest »svedende og gasblå $i$ nakken $»^{37}$ - som det udtrykkes - men som netop har vundet en kamp, hvorfor den anderledes fremtrædelsesform kan ses som noget positivt. De har så at sige mistet deres mulighed for at negere det »almindelige pigeliv«, hvilket får identifikatoriske konsekvenser $i$ den forstand, at investeringen i eliteidræt - og de deraf følgende identifikationer - bliver svære at opretholde. Når grundlaget for at ignorere fraværet af en oplagt identifikationsmulighed forrykkes, må livet - og dermed identifikationen - altså tages op til revurdering. Det er her, fravalget af eliteidrætten dukker op som en klar mulighed. Samtidig er det gennemgående for elitepigerne, at de formulerer overvejelser eller beslutning om et sådant fravalg som noget, der i lige så høj grad handler om et tilvalg af et andet liv. Nemlig som et spørgsmål at kunne deltage i det »almindelige liv«, de ellers har været afskåret fra. Identifikatorisk kan fravalget af elitekarrieren på denne måde forstås som et valg, hvori elitepigerne flytter investeringen, og der- 
med konstitueringen af dem selv, til identifikationsmuligheden »pige-pige«. Fravalget udgør på denne måde en (midlertidig) håndtering af det flertydige identifikatoriske kaos, som i særlig grad er et grundvilkår for elitepigerne.

\section{Afslutning}

I forskningssammenhæng opfattes idræt ofte som en sfære, hvor kønnet i særlig grad forhandles. Judith Butler ${ }^{38}$ har eksempelvis argumenteret for sporten som en arena, hvor opfattelsen af, hvad der skaber den kønnede krop bliver udfordret og forandret, og hvor grænserne for, hvad der konstituerer en mandligt eller kvindeligt kønnet krop, kan overskrides. Som beskrevet peger de i denne artikel anførte undersøgelser af kvindelige idrætsudøvere ligeledes på, at kvinderne aktivt forhandler præsentationer af femininitet og maskulinitet og stiller sig i opposition til traditionelle forestillinger om kvindekønnet. Resultaterne fra undersøgelsen af elitepigerne er $\mathrm{i}$ den forstand ikke overraskende, men kan ses som udtryk for, at pigerne aktivt forhandler deres køn gennem deres tilknytning til elitesporten. På den ene side kan man opfatte det som endnu et eksempel på, at kønnet ikke er fastlåst, og at man som pige kan udvide sine egne udfoldelsesmuligheder. Elitepigernes identifikationsprocesser og praksisser er med til at vise en anden måde at være »pige« på. Det skaber dermed rum for forandring af kønnets betydning - i deres eget liv såvel som på et mere generelt plan. På den anden side kan man se elitepigernes identifikation som en nødvendig nødløsning. Et græsstrå, som de klamrer sig til i forsøget på at forblive accepteret (af sig selv og andre) som piger, samtidig med at de kan udøve den mandsdominerede eliteidræt, de brænder for. Som »drenge-piger« søger de dermed at reartikulere de forskellige elementer i de umulige identiteter, så de ikke helt ekskluderes fra de sociale fællesskaber i og uden for sporten. De stiller således ikke effektivt spørgsmål ved strukturen eller rammerne for kønnenes betydning; men finder en plads i den, der netop ikke kræver et egentligt opgør.

Det bemærkelsesværdige i undersøgelsen af elitepigerne synes således ikke at være den samtidige reproduktion og udfordring af gældende kønskonventioner, men det, vi med et diskursteoretisk perspektiv kan forstå som den radikale - og faktisk oplevede - overdeterminerede situation, elitepigerne står i. Vi ser således sportspigernes identifikationsprocesser som en kamp for at opnå en (i princippet umulig) fuldkommen identitet, der kan indeholde såvel det at være en pige som det at være eliteidrætsudøver. Ved at tage udgangspunkt $\mathrm{i}$ den dobbelte negation af såvel »pige-pige« som »dreng-dreng» konstrueres en dobbelt anderledeshed som det centrale punkt i deres identifikation. Et punkt, der muliggør subjektpositionen »drenge-pige «, men som samtidig gør den midlertidige lukning svær at fastholde og således truer med at destabilisere den sociale situation, pigerne befinder sig i. For at forstå elitepigernes løbende overvejelser om fravalget af eliteidrætten, mener vi således, at det er afgørende at sætte fokus på den paradoksale splittelse, der på én gang muliggør og umuliggør deres identitet. Dette har vi gjort gennem et diskursteoretisk perspektiv og på denne baggrund vist, at elitepigerne konsekvent balancerer på en knivsæg i den identifikatoriske konstituering af sig selv. Det er denne balancegang, der kan tippe og give sig udslag $i$ et helt konkret valg om at indrette sit liv som »almindelige piger« og dermed vælge elitekarrieren fra. 
1 Undersøgelsens titel er »Elitekarriere på spil. En analyse af pigers elitetilværelse mellem samfundsmæssige og idrætslige normer«. Undersøgelsen blev rekvireret og finansieret af Team Danmark på baggrund af henvendelser fra - samt drøftelser med - elitetrænere i undersøgelsens idrætsgrene. Undersøgelsens fokus fremkom idet flere elitetrænere oplever, at piger i nævnte alder af forskellige årsager ikke er motiverede for at satse på eliteidrætten - og træne målrettet i relation hertil - ligesom nogle simpelthen ikke slår igennem, selvom deres talent tegnede til det. Undersøgelsen er et forsøg på at undersøge, hvorfor dette er tilfældet.

2 Der er således tale om et analytisk valg, der kunne være skåret anderledes: Forholdet mellem henholdsvis de normer, der gælder i familien og de normer, der gør sig gældende med venner i forbindelse med uddannelse, kunne ligeledes være udpeget som forskellige kontekster med forskellige dominerende diskurser, havde problemstillingen været en anden. Som vi skal se blev vores analytiske valg katalysator for respondenternes konfliktuelle oplevelser i forhold til at forvalte deres egen rolle som pige.

3 Bech et. al. (2004).

4 Nielsen \& Riiskjær (1983), Hansen (1995), Pedersen (1998), Breivik \& Gilberg (1999), Nielsen et. al. (2000), DIF \& KPMG (2002), Nielsen et. al. (2002).

5 Messner \& Sabo (1990), pp. 3ff.

6 Jf. Messner \& Sabo (1990), pp. v.

7 Messner (2002), pp. xviii ff.

8 Messner \& Sabo (1990).

9 Søndergård (2000), Butler (1993).

10 Dette afspejles ligeledes i temanumre om køn og idræt $\mathrm{i}$ henholdsvis Dansk Sociologi nr.2/2004 samt Kvinder, Køn og Forskning nr. 2-3/2004.

11 Foucault (1986), pp. 220.

12 Chapman (1997).

13 Larsson (2004).

14 Fasting et. al. (2004).

15 Studierne lavet af Chapman og Fasting et. al. viser ved deres forskellighed dermed også, at der kan være afgørende forskelle på, hvorvidt kvinder med deres deltagelse udfordrer den herskende samfundsmæssige konstruktion af femininitet afhængig af, hvilken sportsgren, der er tale om (eksempelvis boksning eller sportsdans).

16 Fx Pedersen (1998), Larsson (2001), Fasting et. al. (2004).

17 Larsson (2001).

18 Larsson (2001).

19 Chapman (1997).

20 Larsson (2001).

21 Bech et. al. (2004), pp. 72.

22 Bech et. al. (2004), pp. 38.

23 Bech et. al. (2004), pp. 97.

24 Bech et. al. (2004), pp. 99.

25 Se Laclau og Mouffe (1985), Laclau (1990), Laclau (1996), Laclau \& Zac (1994), Butler, Laclau, Zizek (2000).

26 Laclau \& Mouffe (1985), pp. 97ff.

27 Laclau \& Mouffe (1985), pp. 105, Laclau (1996), pp. 56. Diskursteorien hviler på en forestilling om, at vi ikke har privilligeret adgang til en umedieret version af virkeligheden. Ifølge diskursteorien skal en diskurs opfattes som materiel, idet der ikke kan skelnes mellem det materielle og det diskursive, jf Laclau og Mouffe (1985).

28 Laclau (1990), pp. 17ff.

29 Laclau \& Mouffe (1985), pp. 111.

30 Laclau (1990), pp.20f, Laclau (1996): pp. 52.

31 Jf. Dyrberg et. al. (2000), pp. 9, Laclau og Mouffe (1985), pp. 112.

32 En sådan dominerende diskurs kalder Laclau og Mouffe en hegemonisk diskurs, dvs. en diskurs, som midlertidigt sætter punktum for kampene om at definere det sociale. Hegemoni er et centralt begreb i diskursteorien, men er udeladt i denne artikel for enkelthedens skyld (for en gennemgang af hegemonibegrebet, se Laclau \& Mouffe (1985)).

33 Bech et. al. (2004), pp. 38.

34 Laclau (1990), pp. 30, Hall (1996), pp. 6.

35 Bech et. al. (2004), pp. 100.

36 Bech et. al. (2004), pp. 41.

37 Bech et. al. (2004): pp. 72.

38 Butler (1998). 


\section{Litteratur}

Bech S, Storm R, Plum M \& Almlund U. Elitekarriere på spil. En analyse af pigers elitetilvcerelse mellem samfundsmassige og idrcetslige normer (København: Team Danmark, 2004).

Breivik G \& Gilberg R. Hvorfor ble de beste best? (Norges Idrettshøgskole, 1999).

Butler J. Bodies that Matter: The Discursive Limits of 'Sex'. (London \& New York, 1993).

Butler J. Athletic Genders: Hyperbolic Instance and/ or the Overcoming of Sexual Binarism. Stanford Humanities Review 6(2) 1998.

Butler J, Laclau E \& Zizek S. Contingency, hegemo$n y$, universality: Contemporary dialogues on the Left (London, 2000).

Chapman G E. Making Weight: Lightweight Rowing, Technologies of Power, and Technologies of the Self«. Sociology of Sports Journal, 14, 1997.

Danmarks Idræts-Forbund \& KPMG. At forene eliteidrcet og uddannelse (København, 2002).

Dyrberg T, Hansen A D \& Torfing J. Diskursteorien på arbejde (Roskilde, 2000).

Fasting K, Pfister G \& Scraton S. Kampen mot kjønnsstereotypiene. Dansk Sociologi nr. 2, 15. årgang, juli 2004.

Foucault M. The subject and power. I: Dreyfus H. L. \& Rabinow P. (red.) Michel Foucault: Beyond Structuralism and Hermeneutics (Brighton, 1986).

Hall S. Introduction: Who Needs 'Identity'? I: Hall S. \& Du Gay P. (red.) Questions of Identity. (London, 1996).

Hall, S. The Question of Cultural Identity. I: Stuart H. et. al. Modernity and its Futures. (London, 1992).

HansenA D. Diskursteori, demokrati og lokaludvalg (København, 2000).

Hansen P J.: Eliteudøvernes vilkår. Undersøgelse af danske eliteidrcetsudøveres idrcetslige og sociale vilkår (København, 1995).
Jørgensen M W \& Phillips L. Diskursanalyse som teori og metode (Roskilde, 1999).

Laclau E. New Reflections on the Revolution of Our Time (London/New York, 1990).

Laclau E. Emancipation(s) (London, 1996).

Laclau E \& Mouffe C. Hegemony and Socialist Strategy (London, 1990).

Laclau E \& Zac Minding the Gab: The Subject of Politics. I Laclau E. (red) The Making of Political Identities (London, 1994).

Larsson H. Iscensättning av kön i idrott. En nutidshistoria om idrottsmannen och idrottskvinann (Stockholm, 2001).

Larsson H. Idrott og genus - kroppens materialisering. Dansk Sociologi nr. 2, 15. årgang, juli 2004.

Lilleaas U B. Maskulinitet, sport og forbudte følelser. Kvinder, køn og forskning, nr. 2-3,13. årg., 2004.

Messner M A \& Sabo D F. (red) Sport, Men and the Gender Order. (Illinois, 1990).

Messner M A.: Taking the Field. Women, Men, and Sports (Minnesota, 2002).

Nielsen K \& Riiskjær S. Eliteidrcetsudøvernes vilkår - Danske eliteidrcetsudøveres sociale, uddannelsesmoessige og økonomiske vilkår samt trceningsog konkurrencebetingelser (København, 1983).

Nielsen K. et. al. Den danske subelites vilkår år 2000. Undersøgelse af subeliteidrcetsudøveres sociale og idrcetslige vilkår. (Roskilde, 2000).

Nielsen K. et. al. Kontraktspillere i fodbold og håndbold. Undersøgelse af sociale, uddannelsesmassige og sportslige vilkår for danske kontraktspillere 2002 (Roskilde \& Hellerup 2002).

Pedersen I K. Den excellente prcestation. Elitesport, kvinder og karriere (København, 1998).

Søndergaard D M. Tegnet på kroppen (København, 2000). 